\title{
Сохранение редких и исчезающих видов луковичных растений во Всероссийском научно-исследовательском институте цветоводства и субтропических культур
}

\section{Conservation of rare and endangered species in the Russian Research Institute of Floriculture and Subtropical Crops}

\author{
Слепченко Н. А. \\ Slepchenko N. A. \\ Всероссийский научно-исследовательский институт ияветоводства и субтропических культур, г. Сочи, Россия. \\ E-mail: slepchenko@vniisubtrop.ru \\ Russian Research Institute of Floriculture and Subtropical Crops, Sochi, Russia
}

\begin{abstract}
Peферат. Создание, пополнение и поддержание генетических коллекций субтропических, южных плодовых, цветочно-декоративных культур является одним из важных направлений исследований во Всероссийском научно-исследовательском институте цветоводства и субтропических культур. Большое внимание уделяется изучению растительного разнообразия, в том числе видов природной флоры, которых насчитывается более 150 таксонов. Луковичные представлены 16 видами, относящимися к пяти семействам. Семь видов имеют статус редкие и исчезающие.
\end{abstract}

Ключевые слова. Биоразнообразие, виды природной флоры, генофонд, луковичные растения, редкие и исчезающие виды, сохранение.

Summary. Creation, replenishment and maintenance of genetic collections of subtropical, southern fruit, and ornamental plants is one of the important research directions in the Russian Research Institute of Floriculture and Subtropical Crops. Much attention is paid to the study of plant diversity, including species from natural flora, which number more than 150 taxa. Bulbous plants are represented by 16 species belonging to five families. Seven species have a rare and endangered status.

Key words. Biodiversity, species from natural flora, gene pool, bulbous plants, rare and endangered species, conservation.

Проблема пополнения, сохранения, рационального использования генетических коллекций растений остается весьма актуальной (Соболева, 2007; Новаковская, Боос, 2015). Одним из направлений деятельности научных учреждений является привлечение в коллекции видов природной флоры, в том числе редких и исчезающих (Гудкова, Мотина, 2018; Рябинина, 2018).

Природная флора Кавказа отличается значительным разнообразием. Однако численность некоторых видов сокращается из-за ухудшения качества природных мест обитаний, сокращения их территорий, усиливающейся рекреационной нагрузки и т.д. Сохранение генофонда эндемичных, редких и исчезающих видов, находящихся под угрозой исчезновения, одна из главных задач, стоящих перед цивилизованным обществом.

Во Всероссийском научно-исследовательском институте цветоводства и субтропических культур (ВНИИЦиСК ) (г. Сочи) создание, пополнение и поддержание генетических коллекций цветочно-декоративных культур являются одними из важных направлений исследований (Рындин, 2015). В настоящее время во ВНИИЦиСК развернута большая работа в этом направлении. Особое внимание уделяется коллекции видов природной флоры. Изучение проводится всесторонне: определяются биоэкологические особенности данных видов (Слепченко, 2012), разрабатываются и усовершенствуются способы размножения растений (Евсюкова и др., 2009; Слепченко, 2010) и сохранения в культуре in vitro (Коломиец и др., 2014, 2015, 2017). 
Коллекция видов природной флоры ВНИИЦиСК в настоящее время включает более 150 таксонов, относящихся к различным жизненным формам (Слепченко и др., 2016). Одной из интереснейших является группа луковичных растений. В ее состав входят 16 видов, относящихся к 5 семействам (табл. 1).

Состав коллекции луковичных видов природной флоры

\begin{tabular}{|c|c|c|}
\hline Семейство & \multicolumn{2}{|c|}{ Количество } \\
\cline { 2 - 3 } & родов & видов \\
\hline Амариллисовые (Amaryllidaceae J. St.-Hil.) & 5 & 6 \\
\hline Аспарагусовые (Asparagaceae Juss.) & 3 & 5 \\
\hline Безвременниковые (Colchicaceae DC.) & 1 & 2 \\
\hline Касатиковые (Iridaceae Juss.) & 2 & 2 \\
\hline Лилейные (Liliaceae Juss.) & 1 & 1 \\
\hline
\end{tabular}

Наибольшее количество видов относятся к семейству Amaryllidaceae - 6 и Asparagaceae -5 . Остальные семейства представлены меньшим количеством видов: Colchicaceae и Iridaceae - по 2, Liliaceae -1 .

Фенологические наблюдения показали, что наибольшее количество видов (семь) цветет в весенний период (около 45 \%), летом зацветает три вида (примерно 19 \%), осенью - пять (более 30 \%), а в зимний период цветет один вид (табл. 2). Луковичные культуры, находящиеся в нашей коллекции, в большинстве своем эфемероиды, отличаются непродолжительным вегетационным периодом, однако выделяются декоративным цветением. Наиболее яркие представители: подснежник Воронова (Galantus woronowii Losinsk), штернбергия желтая (Sternbergia lutea (L.) Spreng.), безвременник яркий (Colchicum laetum Stev.) и др.

Таблица 2

Состав коллекции по срокам начала цветения

\begin{tabular}{|l|c|c|l|}
\hline \multirow{2}{*}{ Период цветения } & \multicolumn{2}{|c|}{ Количество видов } & \multicolumn{1}{|c|}{ Представители } \\
\cline { 1 - 3 } Шимнецветущие & 1 & 6,25 & Galantus woronowii Losinsk \\
\hline Весеннецветущие & 7 & 43,75 & Allium ursinum L., Leucojum aestivum L., Scilla bifolia L. и др. \\
\hline Летнецветущие & 3 & 18,25 & $\begin{array}{l}\text { Lilium caucasicum (Miscz ex Grossh) Grossh., } \\
\text { Pancratium maritimum L., Gladiolus imbricatus L. }\end{array}$ \\
\hline Осеннецветущие & 5 & 31,25 & $\begin{array}{l}\text { Colchicum umbrosum Stev., Sternbergia lutea (L.) Spreng., } \\
\text { Colchicum laetum Stev., Scilla autumnalis L. }\end{array}$ \\
\hline
\end{tabular}

Среди луковичных растений, находящихся в коллекции, имеется семь редких видов, относятся к разным категориям и статусам редкости (Красная книга ..., 2007; Красная книга ..., 2008). Наибольшее количество видов (пять) относятся к «уязвимым» видам. Один вид, «находящийся в критическом состоянии», имеет статус редкости 1А. В коллекции института сохраняются три вида, занесенные в Красные книги субъектов Российской Федерации, эндемичные виды - Galantus woronowii Losinsk., Lilium caucasicum (Miscz ex Grossh) Grossh., Colchicum laetum Stev. и реликтовый вид - Pancratium maritimum L.

Galantus woronowii Losinsk. - Подснежник Воронова. Являясь эндемиком Западного Закавказья, представляет собой редкий, спорадично распространенный колхидско-лазистанский вид с сокращающейся численностью. Региональные популяции относятся к категории редкости «Уязвимые» (Красная книга ..., 2007). В коллекции института с 1993 г. Небольшое растение с ярко-зелеными, с желтоватым оттенком, блестящими линейными листьями с загнутыми вверх краями. Во время цветения длина ли- 
стьев достигает 12-16 см, а после цветения - 18-22 см при ширине 1-2 см. Цветоносы длиной 10-15 см. Цветки одиночные, колокольчатые, поникающие, длиной 2 см и диаметром 2,5 см. Околоцветник белый, венчиковидный, простой, состоит из 6 раздельных лепестков, расположенных в 2 круга. Наружные доли околоцветника обратнояйцевидные, слабовогнутые, внутренние - короче наружных, клиновидные, расширенные вверху, с сердцевидной выемкой и зеленым пятном на верхушке. Луковицы яйцевидные или конические, 2,0-2,5 см в диаметре, с золотистыми чешуйками.

Galanthus woronowii в районе Сочи начинает цвести в конце февраля - начале марта, в отдельные годы -в конце января. Цветение продолжается около месяца, один цветок сохраняет декоративность в течение 3-5 дней. В начале мая листья и цветоносы желтеют и полегают, а в начале июня отмирают (Слепченко, Лобова, 2013).

Leucojum aestivum L. - Белоцветник летний. Евразийский вид с сокращающейся численностью. Региональные популяции относятся к категории редкости «Уязвимые» (Красная книга ..., 2007). В коллекции института с 1993 г. Декоративное растение с линейными, ремневидными, сизовато-зелеными листьями, шириной 1,0-1,5 см. Они обычно длиннее цветоноса. Цветонос безлистный, ребристый, обоюдоострый, до 60 см высотой, несет зонтиковидное, поникающее соцветие, в котором насчитывается от 2 до 7, реже 10 колокольчатых цветков. Цветки длиной до 3 см и диаметром 1,5-3,0 см на цветоножках разной длины. Околоцветник широко-колокольчатый, состоит из шести раздельных, расположенных в два круга, белых долей с зеленым пятнышком на вершине. Луковица яйцевидная, туникатная, 4-5 см в диаметре. В условиях российских субтропиков Leucojum aestivum цветет в апреле-мае, а в некоторые годы - третьей декаде марта. Цветение может продолжаться в течение 30-45 дней. Продолжительность сохранения декоративности соцветиями 5-7 дней. Вегетацию растения заканчивают в июне-июле.

Pancratium maritimum L. - панкраций морской. Средиземноморский реликтовый вид олиготипного рода с локальным распространением (Красная книга ..., 2007). По данным Красной книги Краснодарского края, в начале XXI века в России сохранилось около 10 экземпляров Pancratium maritimum. Региональные популяции относятся к категории «Находящиеся в критическом состоянии». В коллекции института с 1998 г. Крупное растение прибрежной морской зоны, высотой 40-60 см. Развивает пучок плотных, серо-зеленых, линейно-ланцетных листьев и один или несколько серо-зеленых, сплющенных цветоносов. Листья шириной 6-20 мм, плоские, равны или короче стебля. Цветонос несет от одного до 7-10 крупных, пахучих белых цветков, похожих на цветки нарцисса. Соцветие - зонтик, заключенный в двулистное ланцетное крыло. Цветки почти сидячие, окруженные при основании 2 перепончатыми прицветниковыми листьями. Форма цветка изящная, своеобразная, представляющая собой простой венчиковидный околоцветник воронковидной формы с длинной трубочкой, расширяющейся в зеве. Доли околоцветника линейно-ланцетные, отстоящие, почти равные между собой, белые, с зеленой полоской посередине. К зеву прикрепляются 6 тычинок, а между основаниями их нитей натянута перепонка, так называемый «придаточный венчик», или «привенчик», который обыкновенно короче околоцветника, с 12 острыми треугольными зубцами. Луковица крупная, глубоко сидящая, до 10 см длиной и до 6 см в диаметре, многочешуйчатая, одетая темно-бурыми влагалищами. Цветет Pancratium maritimum в июле-августе. Цветение начинается на 5-6 год жизни. Плодоносит в октябре-ноябре.

Lilium caucasicum (Miscz ex Grossh) Grossh. - Лилия кавказская. Являясь эндемиком Кавказа, представляет собой редкий, спорадично распространенный кавказско-переднеазиатский вид с сокращающейся численностью. Региональные популяции относятся к категории редкости «Уязвимые» (Красная книга ..., 2007). В коллекции института с 1993 г. Декоративное луковичное травянистое растение высотой до 115 см. Луковицы небольшие, широкояйцевидные, до 5 см длиной с плотно прилегающими друг к другу чешуями желтого цвета. Стебель крепкий, круглый, густо опушен короткими отстоящими волосками, в верхней части пятнистый, между мутовками без чешуек. Листья обратнояйцевидно-ланцетные или эллиптически-ланцетные, нижние собраны в мутовку по 5-8, верхние - очередные, более короткие, реснитчатые по краю. Цветки по 5-8, до 10 собраны в кисть, поникающие. Доли околоцветника вишнево-розовые с темными пятнышками, продолговатые, до 4 см длиной, суженные книзу, силь- 
но отворочены назад. Тычинки в два раза короче долей околоцветника с темно-пурпурными пыльниками . Столбик в 2 раза длиннее завязи, рыльце трехраздельное. Завязь сидячая, узкая, трехгнездная. Коробочка 6-гранная, с острыми ребрами. Семена многочисленные, округло-треугольной формы, плоские с пленчатыми краями, светло- или темно-коричневые. Цветет Lilium caucasicum в июне. Цветение начинается на 4-5 год жизни. Семена созревают в августе-сентябре и прорастают весной следующего года.

Colchicum laetum Stev. - Безвременник яркий. Южно-европейско-кавказский степной вид. Региональные популяции относятся к категории редкости «Уязвимые» (Красная книга ..., 2007). В коллекции института с 1998 г. Травянистый клубнелуковичный поликарпик высотой до 40 см. Клубнелуковица однолетняя, от обратносердцевидной до удлиненной, яйцевидной, довольно крупная, диаметром около 3 см, высотой 4-5 см. Влагалища кожистые, черно-бурые, вытянутые в довольно длинную, тонкую трубку. Листья сизоватые, широколинейные, серповидно изогнутые, в числе четырех, нижний туповатый, шире остальных, верхние острые, до 20 см длиной и около 4 см шириной. Листья появляются весной одновременно с плодами - коробочками. Весной закладываются и цветки, но цветение происходит в безлистном состоянии осенью этого же года. Околоцветник с длинной (до 20 см) трубкой, довольно крупный, в числе одного-трех, лилово-розовые или пурпурные, доли околоцветника ланцетные или эллиптические, длиной до 4-5 см длиной и 2 см шириной, тупые. Тычинки почти вдвое короче долей околоцветника; пыльники линейные, желтые, длиной до 6-8 см; столбики очень тонкие, нитевидные, почти прямые, на верхушке иногда слегка толще и едва согнутые, во много раз превышают тычинки.

Коробочка яйцевидная, длиной до 2 см, на очень короткой ножке, при основании тупая, на верхушке заостренная. Цветет Colchicum laetum в августе-сентябре. Плодоносит в мае-июле на следующий год. Цветение начинается на 5 год жизни. Хорошо развивается в культуре.

Colchicum umbrosum Stev. - Бевременник теневой. Спорадично распространенный с небольшим числом локалитетов евразийский вид с сокращающейся численностью. Региональные популяции относятся к категории редкости «Уязвимые» (Красная книга ..., 2007). В коллекции института с 1994 г.

Травянистый клубнелуковичный поликарпик высотой, в цветущем состоянии, 11-15 см, при плодоношении - 20-28 см. Клубнелуковица средних размеров, диаметром 1,5-2,0 см, почти шаровидная, при основании часто неравнобокая. Влагалища черно-коричневые, перепончатые, переходящие в длинную тонкую трубку. Листья в количестве 3-5, толстоватые, линейно-ланцетные или ланцетно-ремневидные, тупые, длиной 15 см, шириной 1,5-2,2 см. Листья появляются после цветения весной на следующий год. Цветки в количестве $1-5$, мелкие, появляются осенью. Доли околоцветника эллиптически-обратно-ланцетные, лиловые или бледно-пурпурные, длиной до 2 см (реже 2,5-3 см). Тычинки более чем вдвое короче околоцветника; пыльники желтые, перепончато-окаймленные; столбики едва длиннее тычинок, реже равны им.

Коробочка эллиптически-продолговатая, длиной до 4 см, заостренная, суженная к основанию.

Цветет Colchicum umbrosum в сентябре-октябре. Плодоносит в апреле-мае. Листья и семена развиваются весной, семена прорастают осенью, но развитие проростков продолжается несколько лет, зацветает на четвертый год после прорастания.

Crocus speciosus M.Bieb. - Шафран прекрасный. Евразийский спорадично распространенный вид с ограниченным числом локалитетов. Региональные популяции относятся к категории редкости «Уязвимые» (Красная книга ..., 2007). В коллекции института с 1994 г. Травянистый клубнелуковичный поликарпик высотой 10-30 см. Клубнелуковица в диаметре до 2 см, шаровидная или сплюснуто-шаровидная, покрыта кожистыми чешуями. Листья линейные, длиной до 15 см, шириной 3-4 мм, развиваются после цветения. Цветок крупный, фиолетовый, появляется осенью. Доли околоцветника продолговатые или эллиптически-ланцетные, с тремя пурпурными жилками. Пыльники оранжевые, в 2-3 раза длиннее нитей, рыльца пестика раздельные, оранжевые, значительно превышают пестик. Плод - продолговатая коробочка, при созревании находится на уровне почвы, семена разносятся муравьями. Цветет Crocus speciosus в условиях Сочи в конце октября - начале ноября. Семена созревают в апреле-мае. Зацветает на 4-5 год. 
Работы по сохранению редких и исчезающих видов природной флоры являются весьма актуальными. На базе ВНИИЦиСК продолжаются исследования по изучению и сохранению луковичных растений, в том числе семи редких видов из природной флоры. Коллекция пополняется новыми видами.

\section{ЛИТЕРАТУРА}

Евсюкова Т. В., Козина В. В., Слепченко Н. А. Декоративные травянистые виды природной флоры Северо-Западного Кавказа. - Сочи, 2009. - 35 с.

Гудкова Н. Ю., Мотина Е. A. Сохранение редких и исчезающих растений флоры Крыма и Кавказа в ботаническом саду ВИЛАР // Проблемы ботаники Южной Сибири и Монголии: сб. науч. ст. по материалам XVII междунар. науч.-практ. конф. (24-27 мая 2018 г., Барнаул). - Барнаул: Изд-во АлтГУ, 2018. - С. 466-469.

Коломиеи Т. М., Маляровская В. И., Гвасалия М. В., Самарина Л. С., Соколов Р. Н. Микроразмножение in vitro субтропических, декоративных культур и эндемиков Западного Кавказа: оригинальные и оптимизированные протоколы // Сельскохозяйственная биология, 2014. - № 3. - С. 49-58.

Коломиец Т. М., Маляровская В. И., Губаз С. Л. Создание и поддержание коллекции субтропических плодовых, цветочно-декоративных культур, редких и исчезающих видов растений Западного Кавказа в культуре in vitro // Плодоводство и ягодоводство России, 2015. - Т. ХXXIII. - С. 99-103.

Коломиеи Т. М., Маляровская В. И., Самарина Л. С. Введение в культуру in vitro подснежника Воронова // Субтропическое и декоративное садоводство, 2017. - Вып. 61. - С. 108-114.

Красная книга Краснодарского края. (Растения и грибы) / отв. ред. С. А. Литвинская. - 2-е изд. - Краснодар: ООО «Дизайн Бюро №1», 2007. - 640 с.

Красная книга Российской Федерации (Растения и грибы). / Сост. Р. В. Камелин и др. - М.: Товарищество научных изданий КМК, 2008. -855 с.

Новаковская T. B., Боос $\boldsymbol{A}$. A. Научно-исследовательская работа в Ботаническом саду Сыктывкарского государственного университета им. Питирима Сорокина и перспективы его развития // Вестник современной науки, 2015. - № 9-1. - C. 10-13.

Рындин A. B. 120-летие института - год повышенной ответственности // Плодоводство и ягодоводство России, 2015. - Т. XXXI. - С. 293-304.

Рябинина М. Л. Редкие виды травянистых многолетников в коллекции Ботанического сада Института ботаники Коми НЦ УрО РАН // Проблемы ботаники Южной Сибири и Монголии: сб. науч. ст. по материалам XVII междунар. науч.-практ. конф. (24-27 мая 2018 г., Барнаул). - Барнаул: Изд-во АлтГУ, 2018. - С. 501-504.

Слепченко H. A. Способы размножения редких видов семейства Амариллисовые, произрастающих на Черноморском побережье Кавказа // Субтропическое и декоративное садоводство: сб. науч. тр. - Сочи: ВНИИЦиСК, 2010. - Вып. 43, Том II. - С. 71-75.

Слепченко Н. A. Влияние экологических условий на сезонные циклы развития Leucojum aestivum, Galanthus worowii и Pancratium maritimum // Юг России: экология, развитие, 2012. - № 4. - С. 83-88.

Слепченко Н. А., Лобова Т. Е. Представители семейства Amaryllidaceae Jaume Saint-Hilaire в декоративном садоводстве в субтропической зоне Черноморского побережья России // Субтропическое и декоративное садоводство, 2013. - Вып. 48. - С. 62-72.

Слепченко Н. А., Мишко А. Е., Клемешова К. В. Результаты инвентаризации коллекции видов природной флоры во Всероссийском научно-исследовательском институте цветоводства и субтропических культур // Субтропическое и декоративное садоводство, 2016. - Вып. 58. - С. 61-67.

Соболева М. Н. Коллекция декоративных травянистых многолетников отдела цветоводства Ботанического сада Самарского государственного университета // Самарская Лука: Бюл., 2007. - Т. 16., № 1-2(19-20). - С. 46-57. 